\title{
Problematika Sertipikat Hak Atas Tanah Sebagai Keputusan Tata Usaha Negara
}

\author{
Febby Fajrurrahman \\ Mahasiswa Program Studi Magister Ilmu Hukum Universitas Mataram \\ Email: kangmpeb@gmail.com
}

\begin{abstract}
ABSTRAK
Pasal 19 ayat (1) Undang-undang Nomor 5 Tahun 1960, pokoknya menyatakan: pendaftaran tanah adalah demi kepastian hukum dimana dalam perkembangannya, sertipikat hak atas tanah tak hanya berfungsi sebagai alat pembuktian yang kuat, namun juga bernilai ekonomis tinggi karena dapat dilekati hak accessoir semisal Hak Tanggungan. Sertipikat Hak Atas Tanah tak hanya mengandung kaidah hukum perdata mengenai eksistensi subyek dan obyek hak atas tanah, melainkan juga kaidah hukum administrasi mengenai pengakuan dan aspek legal formal hak atas tanah. Problematika keabsahan sertipikat hak atas tanah dalam penegakan hukum administrasi umumnya berkaitan dengan 3 hal, yakni kewenangan penerbitan, prosedural penerbitan, serta kebenaran substansial. Persoalan yang muncul/berpotensi muncul pasca disahkannya Undang-undang Nomor 30 Tahun 2014, adalah reposisi dan kajian mengenai telah tepatkan sertipikat menjadi obyek dalam sengketa administrasi pertanahan? Disahkannya Undang-undang Nomor 2 Tahun 2012 dan Undang-undang Nomor 30 Tahun 2014, juga berdampak pada perkembangan sengketa administrasi pertanahan, sehingga tak hanya berkenaan dengan gugatan keabsahan sertipikat hak atas, tapi juga aspek lain: sengketa pengadaan tanah serta putusan penerimaan permohonan yang berkaitan dengan administrasi pertanahan. Hal ini menimbulkan gagasan untuk menyelesaikan sengketa tersebut secara terpadu dan holistik di satu pengadilan khusus.
\end{abstract}

Kata Kunci: Sertipikat Tanah, Sengketa Administrasi Pertanahan.

\begin{abstract}
Article 19 paragraph (1) of Law Number 5 Year 1960, principally states: land registration is for the sake of legal certainty in which in its development, the certificate of land rights not only serves as a strong evidence, but also high economic value because it can be covered by accessoir such as Mortgage Rights. Certificate of Right to Land contains not only the rule of civil law concerning the existence of subjects and objects of land rights, but also rules of administrative law regarding the recognition and formal legal aspects of land rights. The problematic validity of certificates of land rights in administrative law enforcement generally relates to 3 matters, namely publishing authority, procedural of publication, and substantial truth. Issues that arise / potentially arise after the passage of Law No. 30 of 2014, is the repositioning and study of the certified has been the object of the land administration disputes? The enactment of Law Number 2 Year 2012 and Law Number 30 Year 2014 also has an impact on the development of land administration disputes, so that not only with respect to the lawsuit of the certificate of the right over, but also other aspects: land acquisition dispute and decision on receipt of related petition with land administration. This raises the idea of resolving the dispute in an integrated and holistic manner in a special court.
\end{abstract}




\section{A. PENDAHULUAN}

Persoalan terkait tanah sebagai sebuah sengketa memiliki kompleksitas yang pelik. Sebagai salah satu unsur utama penopang hidup, tanah tak hanya merupakan identifikasi dari penguasaan penghidupan manusia, tapi juga merupakan simbol kekuasaan, makin luas penguasaan/pemilikan seseorang atas tanah, maka selain tingginya tingkat kesejahteraan akan makin tinggi pula prestise dan kekuasaannya di tengah masyarakat.

Hubungan terhadap tanah yang secara turun temurun sudah berlaku, yang didasarkan pada sifat communal dan magis-religius. Hal tersebut selanjutnya mengalami dualisme, karena konsep hukum pertanahan barat pada masa kolonial secara normatif menghendaki adanya pranata yang baru dalam hubungan hukum manusia dengan tanah, yakni eksistensi hak tanah individual, serta formalitas hak atas dalam bentuk pendaftaran hak atas tanah: (sertifikasi).

Hak individual atas tanah berarti bahwa setiap orang dapat secara maksimal mengambil keuntungan dan memanfaatkan hak atas tanahnya, semata untuk kepentingannya sendiri, sementara pendaftaran hak atas tanah menempati posisi vital untuk menjamin kelancaran dan juga memberikan kepastian serta perlindungan hukum bagi seseorang dalam melaksanakan hak individual atas tanahnya itu.

Hal tersebut kemudian juga sejalan dan ternormakan dalam ketentuan Pasal 19 ayat (1) Undang-undang Nomor 5 Tahun 1960, yang pada pokoknya menyatakan bahwa pendaftaran tanah bertujuan demi kepastian hukum mengenai eksistensi hak atas tanah. Output dari pendaftaran tanah adalah berbentuk Buku Tanah \& Gambar Situasi/Surat Ukur, sebagaimana dimaksud dalam ketentuan Pasal 19 ayat (2) Undangundang Nomor 5 Tahun 1960 yang

Open Correctional

Institution

disimpan di Kantor Pertanahan. Sementara tanda bukti hak bagi pemegang hak merupakan perpaduan antara keduanya, dalam bentuk sertipikat yang memuat eksistensi Hak Atas Tanah dan Gambar Situasi/Surat Ukur.

Dalam perkembangannya, Sertipikat Hak Atas Tanah tak hanya berfungsi sebagai suatu alat pembuktian yang kuat sebagaimana dimaksud dalam ketentuan Pasal 19 ayat (2) huruf c Undang-undang Nomor 5 Tahun 1960 maupun Pasal 32 ayat (2) Peraturan Pemerintah Nomor 24 Tahun 1997, namun juga terhadapnya dapat dilekati status hukum lain yang bersifat accessoir semisal Hak Tanggungan, ataupun kedudukannya dalam praktik penegakan hukum administrasi sebagai sebuah keputusan tata usaha Negara sebagaimana dimaksud dalam Pasal 1 angka 9 Undang-undang Nomor 51 Tahun 2009.

Sengketa pertanahan yang bersifat administratif terjadi akibat dikeluarkannya keputusan tata usaha negara yang mengandung unsur kesalahan atau kekeliruan dalam penetapan hak atas tanah dan pendaftarannya.

Problematika keabsahan sertipikat hak atas tanah dalam kajian penegakan hukum administrasi pada umumnya berkaitan dengan 3 hal utama, yakni kewenangan penerbitan, prosedural penerbitan, serta kebenaran substansial produk hukum tersebut.

Disahkannya Undang-undang Nomor 2 Tahun 2012 dan Undang-undang Nomor 30 Tahun 2014, juga berdampak pada perkembangan sengketa administrasi pertanahan, sehingga tak hanya berkenaan dengan obyek berupa sertipikat hak atas saja, tapi juga obyek lain yakni sengketa pengadaan tanah dan putusan penerimaan permohonan.

Rumusan masalah adalah: Bagaimana konsep dasar hak atas tanah dan kedudukan Sertipikat Hak Atas Tanah 
sebagai Keputusan Tata Usaha Negara dalam penegakan Hukum Administrasi? Apa problematika hukum dalam kaitan Sertipikat Hak Atas Tanah sebagai Keputusan tata usaha negara? Bagaimanakah penegakan Hukum Administrasi dalam sengketa di bidang pertanahan, khususnya berkaitan dengan Sertipikat Hak Atas tanah?

\section{B. PEMBAHASAN}

\section{Konsep Dasar Hak Atas Tanah dan Kedudukan Sertipikat Hak Atas Tanah sebagai Keputusan Tata Usaha Negara}

Disahkannya UUPA memang secara legal-formal telah meniadakan dualisme penerapan hukum agraria yang berlaku di Indonesia, yakni dihapuskannya Hukum Agraria Kolonial menjadi Hukum Agraria Nasional. Akan tetapi merujuk pada ketentuan Pasal 3 UUPA, sebenarnya Hukum Agraria Nasional pun masih secara terbuka mengakui eksistensi penerapan kaidah dan hukum agraria adat, sepanjang menurut kenyataannya masih ada.

Menurut Budi Harsono sistem hakhak penguasaan atas tanah dalam UUPA sebagai Hukum Tanah Nasional, dimulai daril:

1. Hak Bangsa Indonesia, sebagai hak penguasaan atas tanah yang tertinggi, beraspek hukum keperdataan dan publik;

2. Hak Menguasai dari negara yang bersumber pada Hak Bangsa dan beraspek hukum publik semata, pelaksanaan sebagian kewenangannya dapat dilimpahkan kepada pihak laun dalam bentuk hak Pengelolaan;

3. Hak-hak penguasaan individual yang terdiri atas hak-hak atas tanah, wakaf, hak jaminan atas tanah yang disebut hak tanggungan.

Berdasarkan pada pendapat dan

${ }^{1}$ Budi Harsono, Hukum Agraria Indonesia: Sejarah Pembentukan Undang-undang Pokok Agraria, Isi dan Pelaksanaannya, cetakan ke-12, Djambatan, Jakarta, 2008, halaman 208-209 ketentuan tersebut, maka konsepsi hak atas tanah dalam UUPA secara tipikal dapat dibagi menjadi 2 golongan besar, yakni hak komunal (hak bangsa Indonesia) yang beraspek hukum keperdataan dan hukum publik, serta hak indvidual yakni hak-hak atas tanah yang bersumber dari hak bangsa Indonesia maupun hak menguasai negara.

Menurut penulis, Hak Bangsa Indonesia merupakan muasal hak atas tanah yang pertama. Hak ini merupakan domain dari seluruh rakyat Indonesia sebelum terpersonifikasikan dalam bentuk Negara maupun pemerintahan. Hak Bangsa Indonesia atas tanah sebagaimana Hak Asasi Manusia, eksis semata karena keberadaan rakyat dan didapatkan secara otomatis sepanjang ia dilahirkan di wilayah negara Indonesia (dengan merujuk pada asas kewarganegaraan ius soli), maupun memilih menjadi bagian dari rakyat negara Indonesia (dengan merujuk pada asas kewarganegaraan ius sanguinis).

Hubungan yang erat dan tidak terpisahkan antara manusia dengan tanah menjadi dasar atas prinsip komunalistik religius yang terkandung dalam UUPA. Hukum tanah nasional yang dilandasi konsep hukum adat yang mengandung prinsip komunalistik religius yang memungkinkan adanya penguasaan tanah secara individual dengan hak-hak atas tanah yang bersifat pribadi sekaligus mengandung kebersamaan2. Konsepsi yang mendasari UUPA adalah konsepsinya Hukum Adat (komunalistik religius) yang memungkinkan penguasaan tanah secara individual, dengan hak-hak atas tanah yang bersifat pribadi sekaligus mengandung unsur kebersamaan3.

Hak atas tanah yang dimiliki individual (orang maupun badan hukum) yang merupakan turunan dari Hak Bangsa Indonesia serta Hak Menguasai Negara, terbatasi oleh konsep Hak komunal

\footnotetext{
${ }^{2}$ Muhammad Ilham Arisaputra, Reforma Agraria Di Indonesia, Sinar Grafika, Jakarta Timur, 2015, hlm. 66-67.

Nia Kurniati, Hukum Agraria: Sengketa Pertanahan Penyelesaiannya Melalui Arbitrase Dalam Teori dan Praktik, Refika Aditama, Bandung, 2016, halaman 41.
} 
(bersama) berdasarkan Hak Bangsa Indonesia serta Hak Menguasai Negara itu juga. Hak atas tanah individual tidak bersifat mutlak, sebab sewaktu-waktu dapat dinyatakan hapus/hilang baik dengan pencabutan, penyerahan maupun dengan tidak dilakukannya pemanfaatan/ pendayagunaan tanah tersebut secara sengaja. Sehingga kendatipun secara normatif hak individual diakui keberadaannya, akan tetapi secara konsepsi hak atas tanah tetap merujuk dan berdasarkan pada hak-hak komunal berdasarkan prasyarat pemanfaatan/ pendayagunaan tanah secara optimal.

Hak bangsa merupakan hak penguasaan atas tanah yang tertinggi dalam Hukum Tanah Nasional. Hak-hak penguasan atas tanah yang lain, secara langsung maupun tidak langsung bersumber padanya. Hak Bangsa mengandung dua unsur, yaitu unsur kepunyaan dan unsur tugas kewenangan untuk mengatur dan memimpin pengasaan dan penggunaan bersama yang dipunyainya. Hak Bangsa tersebut, bukanlah hak pemilikan dalam pengertian yuridis4.

Pendaftaran hak atas tanah sebagaimana ketentuan Pasal 19 ayat (1) UUPA yang kemudian dilaksanakan baik berdasarkan Peraturan Pemerintah Nomor 10 Tahun 1961, maupun melalui Peraturan Pemerintah Nomor 24 Tahun 1997, lebih menitikberatkan pada aspek kepastian hukum dalam hal eksistensi hak atas tanah. Pendaftaran tanah hakikatnya merupakan tindakan untuk me-legal-formal-kan hubungan hukum antara subyek hukum (orang atau badan hukum) dengan obyek hukum (tanah) melalui instrumen hukum publik, hak mana yang sebenarnya secara substansial telah ada berdasarkan kaidah hukum keperdataan.

Pendaftaran berasal dari bahasa Belanda "cadastre", suatu istilah teknis untuk record (rekaman), yang merujuk

${ }^{4}$ Elza Syarief, Menuntaskan Sengketa Tanah Melalui Pengadilan Khusus Pertanahan, Kepustakaan Populer Gramedia, Jakarta, 2004, halaman 135. pada luas, nilai, dan kepemilikan (atau lain-lain alas hak) terhadap suatu bidang tanah. Kata ini berasal dari bahasa Latin "capitastrum" yang berarti suatu register atau kapita atau unit yang diperbuat untuk pajak tanah Romawi (Capotatio Terrens). Dalam artian cadastre adalah rekaman daripada lahan-lahan, nilai daripada tanah dan pemegang haknya dan untuk kepentingan perpajakan5.

Pendaftaran tanah merupakan pencatatan identitas sebidang tanah pada Kantor Pertanahan Kota/Kabupaten yang nantinya akan menghasilkan sebuah sertifikat tanah sebagai bukti yang kuat, sehingga jelas jenis haknya, luasnya, batasbatasnya, keadaannya, letaknya serta pemiliknya. Kewajiban untuk melakukannya pada prinsipnya dibebankan pada pemerintah dan pelaksanaannya dilakukan secara bertahap6.

Selain persoalan kepastian hukum, pendaftaran hak atas tanah juga berkenaan dengan aspek keadilan pendistribusian tanah. Mengingat keterbatasan persediaan tanah yang relatif tetap dibanding dengan jumlah penduduk yang terus berkembang, maka diperlukan pembatasan penguasaan/pemilikan tanah7. Penguasaan dan pemilikan tanah yang tidak berimbang, dimana tanah dengan luasan tertentu ternyata hanya dimiliki oleh segelintir orang saja, dapat menjadi sumber konflik pertanahan karena ketiadaan akses tanah yang berakibat pada kesenjangan taraf kehidupan disebabkan keterbatasan pemenuhan kebutuhan dan penghidupan.

Dokumentasi dan pemeliharaan data terkait hak atas tanah oleh Badan Pertanahan Nasional, memastikan bahwa subyek hukum hanya akan memiiki hak atas tanah sesuai dengan yang seharusnya. Selain itu, dapat ditelusur juga jenis

\footnotetext{
5 AP. Parlindungan, Pendaftaran Tanah Di Indonesia, Mandar Maju, Bandung, 1999, halaman 18.

${ }^{6}$ Maria SW Kebijakan Pertanahan. Antara Regulasi dan Implementasi, Cetakan VI, Penerbit Buku Kompas, Jakarta, 2009, halaman 181.

7 Rusmadi Murad, Menyingkap Tabir Masalah Pertanahan, Penerbit Mandar Maju, Bandung, 2000, halaman 62.
} 
pemanfaatan tanah tersebut apakah telah dilakukan sesuai dengan peruntukannya ataukah tidak. Yang pada akhirnya tentunya berintikan pendayagunaan dan pemanfaatan tanah secara optimal dan berkeadilan demi kesejahteraan bersama.

Kekuatan berlakunya sertipikat telah ditegaskan dalam Pasal 19 ayat (2) huruf c dan Pasal 32 ayat (1) Peraturan Pemerintah Nomor 24 Tahun 1997, yakni sertipikat merupakan tanda bukti hak yang berlaku sebagai alat pembuktian yang kuat mengenai data fisik dan data yuridis yang termuat di dalamnya, sepanjang data fisik dan data yuridis sesuai dengan data yang ada di dalam surat ukur dan buku tanah yang bersangkutan 8 .

Dari segi bisnis, tanah yang telah bersertipikat (alas haknya berbentuk sertipikat), akan memiliki nilai ekonomis yang lebih tinggi bila dibandingkan dengan tanah yang belum bersertipikat (alas haknya berbentuk Akta Jual Beli, Surat Keterangan Tanah, Surat Pernyataan Penguasan Fisik, Persil, maupun dokumen lain yang dianggap sebagai alas hak atas tanah).

Merujuk pada konsep pendaftaran tanah, baik dalam Peraturan Pemerintah Nomor 10 Tahun 1961 maupun Peraturan Pemerintah Nomor 24 Tahun 1997, sistem pendaftaran tanah yang dianut adalah stelsel negatif. Sejalan pula dengan apa yang diungkapkan Adrian Sutedi, bahwa Pendaftaran tanah menurut Peraturan Pemerintah Nomor 24 Tahun 1997 menggunakan sistem publikasi negatif. Dalam sistem ini negara hanya secara pasif menerima apa yang dinyatakan oleh pihak yang meminta pendaftaran9.

Dalam melaksanakan setiap perbuatan administrasi Negara tersebut, pemerintah (bestuur) sebagai personifikasi dari Negara harus mendasarkan diri pada peraturan perundang-undangan dan/atau asas-asas umum pemerintahan yang baik, sebagaimana pemaknaan a contrario

8 Adrian Sutedi, Sertifikat Hak Atas Tanah, Sinar Grafika, Jakarta, 2014, hlm. 29

${ }^{9}$ ibid, halaman 96. terhadap norma yang termuat dalam Pasal 53 ayat (2) Undang-undang Nomor 9 Tahun 2004.

Perbuatan tata usaha Negara (bestuurhandelingen) dalam kepustakaan hukum administrasi Negara dapat diklasifikasikan atas perbuatan materiil/nyata (feitelijk handeling) dan perbuatan hukum (rechthandeling). Perbuatan materiil10 adalah perbuatan yang dilakukan oleh badan atau pejabat TUN untuk memenuhi kebutuhan nyata yang tidak dimaksudkan untuk menimbulkan akibat hukum11.

Lebih lanjut dalam praktiknya, perbuatan administrasi negara (bestuurhandelingen) kerap diidentikkan secara spesifik dengan pelaksanaan urusan pemerintahan, yang tentu bersinggungan dengan tindakan administrasi maupun penerbitan keputusan administrasi Negara. Sejalan dengan pendapat dari H.J Romeijn, bahwa tindakan hukum administrasi (administratieve rechthandelingen) merupakan suatu pernyataan kehendak yang muncul dari organ administrasi dalam keadaan khusus, dimaksudkan untuk menimbulkan akibat hukum dalam bidang hukum administrasi12.

Philipus M. Hadjon menyatakan bahwa pada umumnya feitelijke handeling selalu dikemukakan sebagai jenis perbuatan pemerintah yang berdiri sendiri dan ditempatkan secara terpisah dari jenis pengelompokan perbuatan hukum (rechthandelingen) pemerintahan 13 . Pembedaan yang diberikan terhadap kedua perbuatan pemerintah itu didasarkan pada terdapat atau tidaknya akibat hukum (rechtsgevolg) dari perbuatan pemerintah

\footnotetext{
${ }^{10}$ Terhadap istilah ini, penulis menilai perlu membedakan perbuatan materiil sebagai padanan dari feitelijk handeling, dengan perbuatan materiil sebagai terjemahan dari Materiale Daad. Sehingga dalam peristilahan selanjutnya, penulis lebih memilih menggunakan padanan kata perbuatan nyata atau perbuatan faktual sebagai terjemahan dari feitelijk handeling.

${ }^{11}$ Philipus M. Hadjon, dkk. Pengantar Hukum Administrasi Negara Indonesia, UGM Press, Yogyakarta, 1994, hlm. 175-178.

${ }^{12}$ H.J. Romeijn dalam Ridwan HR, Hukum Administrasi Negara, PT RajaGrafindo Persada, Jakarta, 2006, halaman 13

${ }^{13}$ Philipus M. Hadjon, dkk . op.cit., halaman 176
} 
yang bersangkutan 14 .

Dari rumpun perbuatan hukum (rechtshandelingen), terdapat tipikal perbuatan hukum tata usaha Negara, yakni perbuatan hukum yang dilakukan oleh badan atau pejabat tata usaha Negara berdasarkan norma hukum tata usaha Negara dan dimaksudkan untuk menimbulkan akibat hukum tertentu, yaitu berupa hak dan kewajiban bagi seseorang atau badan hukum perdata yang dituju.

Indroharto mendefinisikan bahwa tindakan dalam lingkup administrasi Negara in cassu penerbitan sebuah produk hukum, ada yang bersifat abstrak, umum, final, dan ada pula yang bersifat konkrit, individual dan final15. Implementasinya jelas, jenis tindakan yang pertama dengan output berupa regulasi atau peraturan perundang-undangan (regeling), melekat kewenangannya pada legislative dan/atau eksekutif dalam kategori tertentu. Sementara jenis tindakan yang kedua dengan output berupa keputusan atau penetapan (beschikking), melekat kewenangannya pada badan/jabatan administrasi yang tentu proporsinya lebih besar berada pada lingkup eksekutif.

Perbuatan pemerintah yang diakukan merupakan perbuatan hukum (rechtshandelingen), yang menimbulkan akibat-akibat hukum tertentu dan dituangkan dalam bermacam-macam keputusan16. Keputusan dapat pula dibedakan antara keputusan konstitutif dan keputusan deklaratoir.

Keputusan konstitutif adalah suatu keputusan yang menimbulkan hak baru bagi seseorang yang namanya tercantum dalam keputusan itu, dimana hak itu tidak dipunyai sebelumnya (rechtsscheppende beschikking). Keputusan konstitutif sering disebut keputusan yang "menentukan" dan merupakan bagian dari keputusan positif,

\footnotetext{
${ }^{14}$ ibid, halaman 177.

${ }^{15}$ Indroharto, Usaha Memahami Undang-undang Tentang Peradilan Tata Usaha Negara, Buku I, Pustaka Sinar Harapan, Jakarta, 2000, hlm. 144-145.

16 SF. Marbun, Peradilan Administrasi dan Upaya Administrasi di Indonesia, Penerbit UII Press, Yogyakarta, 2003., halaman 102.
}

sedangkan keputusan deklaratoir adalah keputusan untuk mengakui suatu hak yang telah ada dan diberikan karena telah memenuhi syarat-syarat yang ditentukan. Pemberian keputusan deklaratoir dilakukan untuk mewujudkan suatu ketentuan dalam undang-undang yang masih bersifat abstrak ke dalam bentuk peristiwa konkret.

Secara normatif, pengertian keputusan tata usaha negara diatur dalam Pasal 1 angka 9 Undang-undang Nomor 51 Tahun 200917, yakni suatu penetapan tertulis yang dikeluarkan oleh badan atau pejabat tata usaha negara yang berisi tindakan hukum tata usaha negara yang berdasarkan peraturan perundangundangan yang berlaku, yang bersifat konkret, individual, dan final, yang menimbulkan akibat hukum bagi seseorang atau badan hukum perdata.

Dalam perkembangannya, konsep maupun norma keputusan tata usaha negara mengalami perubahan dalam bentuk ekstensif, yakni perluasan makna dan cakupan yuridis, sebagaimana tertuang dalam Undang-undang Nomor 30 Tahun 2014 tentang Administrasi Pemerintahan.

Pemaknaan baru yang bersifat ekstensif (perluasan makna) terhadap keputusan administrasi pemerintah, dituangkan dalam ketentuan Pasal 87, yang berbunyi:

Dengan berlakunya Undang-Undang ini, Keputusan Tata Usaha Negara sebagaimana dimaksud dalam UndangUndang Nomor 5 Tahun 1986 tentang Peradilan Tata Usaha Negara sebagaimana telah diubah dengan Undang-Undang Nomor 9 Tahun 2004 dan Undang-Undang Nomor 51 Tahun 2009, harus dimaknai sebagai:

a. penetapan tertulis yang juga mencakup tindakan faktual;

b. Keputusan Badan dan/atau Pejabat Tata Usaha Negara di lingkungan eksekutif, legislatif, yudikatif, dan penyelenggara negara lainnya;

${ }^{17}$ Sebelumnya diatur dalam ketentuan Pasal 1 angka 3 Undang-undang Nomor 5 Tahun 1986. 
c. berdasarkan ketentuan perundangundangan dan AUPB;

d. bersifat final dalam arti lebih luas;

e. Keputusan yang berpotensi menimbulkan akibat hukum; dan/atau

f. Keputusan yang berlaku bagi Warga Masyarakat.

Adanya perluasan makna terhadap keputusan tata usaha negara ini, tentu berimplikasi pula pada ruang lingkup kewenangan Peradilan Administrasi/Peradilan Tata Usaha Negara untuk menegakkan hukum administrasi. Legal standing masyarakat pun menjadi kian terbuka, tatkala terdapat klausul normatif yang memungkinkan dipersoalkannya setiap fase tindakan maupun keputusan yang dilakukan oleh Badan/Pejabat Pemerintahan, yang dianggap merugikan mereka.

Dalam praktik penegakan hukum administrasi selama ini, khususnya berkenaan dengan sengketa di bidang pertanahan, yang diposisikan sebagai obyek sengketa in cassu keputusan tata usaha negara adalah sertipikat hak atas tanah. Hal ini telah menjadi doktrin yang berlaku di seluruh Peradilan Tata Usaha Negara, salah satunya didasarkan pada Yurisprudensi Mahkamah Agung, yakni Nomor 140 K/TUN/2000, tanggal 11 Februari 2002, yang pada pokoknya menyatakan bahwa: "Sertipikat tanah termasuk keputusan tata usaha negara deklarator, artinya di balik keputusan tersebut terdapat pemegang hak yang sebenarnya (de ware rechtstitel).

Pembuatan sertifikat hak atas tanah sebagai bentuk keputusan tata usaha negara harus memperhatikan persyaratan agar keputusan tersebut menjadi sah menurut hukum (rechtsgeldig) dan memiliki kekuatan hukum (rechtskracht). Syaratsyarat yang harus diperhatikan dalam pembuatan keputusan ini mencakup syarat materiil dan syarat formil.

Dengan adanya perluasan makna terhadap konteks keputusan tata usaha negara berdasarkan Undang-undang
Nomor 30 Tahun 2014, tentu secara logis akan membawa pergeseran pula pada penempatan obyek sengketa dalam sengketa di bidang pertanahan. Beberapa opsi pernah dibahas dalam pelatihan Hakim Peradilan Tata Usaha Negara, tentang fase dan produk hukum pertanahan mana yang kemudian dapat dijadikan obyek sengketa di Peradilan Tata Usaha Negara. Apakah tetap merujuk pada sertipikat, atau Surat Keputusan Pemberian Hak (SKPH), atau dokumen/produk hukum lainnya.

\section{Problematika Penegakan Hukum Administrasi dalam Sengketa di Bidang Pertanahan.}

Prajudi Admosudirjo menyatakan bahwa beschikking lahir dari suatu permohonan 18, hal mana yang menurut penulis pun juga berlaku dalam berbagai tindakan hukum pemerintahan lainnya. Penerbitan suatu produk hukum berbentuk keputusan administrasi, selalui didahului oleh adanya permohonan dari yang berkepentingan.

Sertipikat hak atas tanah adalah produk pemerintah yang lahir karena hukum dan konkrit sifatnya karena ditujukan untuk subyek dan obyek yang ditentukan. Sertifikat hak atas tanah juga bersifat individual dan final karena tidak ditujukan untuk masyarakat umum akan tetapi hanya bagi mereka yang tercantum dalam sertifikat tersebut serta tidak memerlukan persetujuan instansi lain. Bila dilihat dari akibat yang ditimbulkan maka tindakan pemerintah dalam kegiatan pemberian Sertipikat Hak Atas Tanah adalah bertujuan untuk menimbulkan keadaan hukum baru (rechtscheppende/constitutieve beschikking) sehingga lahir pula hak-hak dan kewajiban-kewajiban hukum tertentu19.

Sengketa pertanahan menurut Sarjita

\footnotetext{
${ }^{18}$ Philipus M. Hadjon, dkk., op.cit. halaman 143.

19 Dani Elpah, Titik Singgung Kewenangan Antara Peradilan Tata Usaha Negara Dengan Peradilan Umum Dalam Sengketa Pertanahan, Laporan Penelitian, Bogor, Balitbang Diklatkumdil, 2014, halaman 5-6.
} 
adalah perselisihan yang terjadi antara dua pihak atau lebih yang merasa atau dirugikan pihak-pihak tersebut untuk penggunaan dan penguasaan hak atas tanah, yang diselesaikan melalui musyawarah atau melalui pengadilan 20. Pendapat ini lebih condong kepada sengketa pertanahan dalam hak keperdataan (kepemilikannya), sebab lebih menekankan pada pelaksanaan maupun hambatan hak-hak atas tanah perseorangan. Sementara dalam sengketa pertanahan dari aspek administrasi, tidak hanya terbatas pada penggunaan dan penguasaan hak atas tanah, melainkan juga aspek legal-formal hak atas tanah yang tentu melibatkan badan/pejabat tata usaha negara, serta kewenangan berdasarkan kaidah hukum publik yang ada padanya, untuk menerbitkan keputusan terkait hak atas tanah itu. Maka pengujian yang dilakukan terhadapnya, bersifat pengujian keabsahan sertipikat hak atas tanah dari aspek administrasi negaranya.

Dilihat dari segi yuridis praktis, sengketa dalam bidang pertanahan dapat diklasifikasi menjadi21:

1) Masalah perdata pertanahan, seperti yang timbul akibat jual beli dan sewamenyewa tanah, pembebanan hak tanggungan atas tanah atau pewarisan;

2) Masalah pidana pertanahan, antara lain penyerobotan tanah, penggarapan tanah yang tidak dilakukan secara legal, serta yang terkait dengan usnur penipuan, pencurian dan yang lain;

3) Masalah pertanahan yang berkaitan dengan keputusan instansi atau pejabat pemerinyahan, misalnya tumpang tindihnya aturan pertanahan serta penetapan keputusan eksekusi pertanahan yang tidak dapat dijalankan.

Gugatan kepada pengadilan tersebut dikarenakan sertipikat mempunyai 2 (dua) sisi, yakni secara keperdataan merupakan alat bukti pemilikan, di sisi lain sertipikat

\footnotetext{
${ }^{20}$ Sarjita, Teknik dan Strategi Penyelesaian Sengketa Pertanahan, Tugojogja Pustaka, Yogyakarta, 2005, halaman 8.

${ }^{21}$ Arie S. Hutagalung, Tebaran Pemikiran Seputar Masalah Hukum Tanah, Lembaga Pemberdayaan Hukum Indonesia, Jakarta, 2005, halaman 379-385.
}

merupakan bentuk keputusan yang bersifat penetapan (beschikking) yang diterbitkan oleh Kepala Kantor Pertanahan sebagai Pejabat Tata Usaha Negara, yang bersifat beschikking merupakan pengakuan hak milik atas tanah bagi pemiliknya22.

Seperti halnya sengketa administrasi pada umumnya, pengujian keabsahan dari sertipikat hak atas tanah meliputi 3 pokok pengujian utama, yakni: (1) apakah sertipikat tersebut diterbitkan oleh Badan/Pejabat Pemerintah yang memiliki kewenangan (aspek kewenangan); (2) apakah sertipikat tersebut dalam penerbitannya telah menempuh tahapantahapan yang tepat dan lengkap sesuai dengan peraturan perundang-undangan (aspek prosedural); dan (3) apakah sertipikat tersebut diterbitkan dengan datadata yang benar, akurat dan obyektif, serta didasari dari adanya iktikad baik dari pemohon maupun pelaksana pendaftaran tanah sesuai dengan peraturan perundangundangan maupun asas-asas umum pemerintahan yang baik (aspek substansial).

Sengketa tata usaha negara dengan klasifikasi pertanahan merupakan sengketa dengan jumlah paling banyak, hampir merata di seluruh Pengadilan Tata Usaha Negara di Indonesia. Mayoritas dari sengketa tersebut tentu mendudukkan sertipikat hak atas tanah sebagai obyek sengketanya. $^{23}$

Selain sengketa administrasi pertanahan dengan obyek sengketa berupa sertipikat hak atas tanah, dengan disahkannya Undang-undang Nomor 2 Tahun 2012 dan Undang-undang Nomor 30 Tahun 2014, maka sengketa tata usaha negara atau sengketa administrasi yang berkaitan dengan pertanahan, secara praktis dapat digolongkan menjadi 3 golongan besar, yakni mengenai:

\footnotetext{
${ }^{22}$ Adrian Sutedi, op. cit. halaman 3

23 Direktorat Jenderal Badan Peradilan Militer dan Peradilan Tata Usaha Negara Mahkamah Agung Republik Indonesia, Statistik Perkara Peradilan Tata Usaha Negara Seluruh Indonesia Tahun 2015, Jakarta, 2016, halaman 28.
} 
1) Keabsahan sertipikat hak atas tanah dan/atau Surat Keputusan Hak Atas Tanah. Ini termasuk dalam sengketa tata usaha negara pada umumnya. (Pasal 1 angka 10 Undang-undang Nomor 51 Tahun 2009);

2) Tidak diprosesnya Permohonan Penerbitan Sertipikat Hak Atas Tanah. Dalam praktek peradilan, lebih dikenal istilah Sengketa Administrasi Fiktif Positif, yakni Putusan Penerimaan Permohonan. (Pasal 53 ayat (4) s/d ayat (6) Undang-undang Nomor 30 Tahun 2014);

3) Sengketa Pengadaan Tanah Bagi Pembangunan Untuk Kepentingan Umum. (Pasal 23 Undang-undang Nomor 2 Tahun 2012);

\section{Penegakan Hukum Administrasi dalam Sengketa di Bidang Per- tanahan.}

Berdasarkan telaahan penulis terhadap beberapa sengketa tata usaha negara (gugatan) di beberapa Pengadilan Tata Usaha Negara di Indonesia yang diambil secara acak dalam rentang waktu tahun 2010 sampai dengan tahun 2015, sebagaimana telah terangkum dalam tabel 1, mayoritas sengketa administrasi di bidang pertanahan berbentuk sengketa tata usaha negara biasa (gugatan) menempatkan Sertipikat Hak Atas Tanah yang diterbitkan oleh Badan Pertanahan Nasional (atau instansi bawahannya) sebagai obyek sengketa. Hanya sedikit (sekitar 4) sengketa administrasi pertanahan yang memiliki obyek selain Sertipikat Hak, yakni dalam bentuk Surat Pernyataan Penguasaan Fisik Bidang Tanah, Pembukuan Letter C serta tindakan administrasi berupa penolakan legalisasi Surat Pernyataan Penguasaan Fisik Bidang Tanah, pencatatan peralihan hak dan penolakan proses penerbitan sertipikat.

Pembatalan24 suatu sertipikat hak

${ }^{24}$ Kendatipun sebenarnya gugatan keabsahan sertipikat dapat pula memiliki output berupa diputuskan mengenai tidak sahnya suatu sertipikat akibat ketiadaan kewenangan penerbitannya, akan tetapi lebih banyak proporsi illegalitas sertipikat disebabkan aspek prosedural-substansial, dibandingkan aspek kewenangan. atas tanah berdasarkan telaahan penulis, proporsinya lebih banyak disebabkan karena:

a. tidak ditempuh dan tidak dilakukannya pengukuran bidang dan batas bidang tanah dengan benar;

b. pengabaian fase penelitian dan/atau pengumuman data fisik dan data yuridis bidang tanah yang dimohonkan haknya;

c. penetapan yang absurd atau inkonsisten mengenai pemberian hak atas tanah negara; atau

d. kombinasi diantara ketiga hal tersebut.

Fase pengukuran bidang dan batas bidang tanah sebagaimana ketentuan Pasal 14, Pasal 17 dan Pasal 18 ayat (1) dan ayat (4) Peraturan Pemerintah Nomor 24 Tahun 1997 jo. Pasal 19, Pasal 77 s/d Pasal 80 Peraturan Menteri Negara Agraria/Kepala Badan Pertanahan Nasional Nomor 3 Tahun 1997, pada prinsipnya merupakan manifestasi dari asas publisitas dari penerbitan sertipikat, yakni bahwa segala tahapan penerbitan sertipikat harus memungkinkan dan memberikan kesempatan yang fair bagi tiap-tiap subyek hukum yang mendalilkan berkepentingan terhadapnya.

Terdapat konflik penafsiran dalam implementasinya. Tanah yang didaftarkan dan berasal dari pemberian hak yang berasal tanah negara berdasarkan Peraturan Menteri Negara Agraria/Kepala Badan Pertanahan Nasional Nomor 9 Tahun 1999, secara substansial tidak memuat norma mengenai kewajiban mengumumkan proses pendaftaran tanah, agar diketahui pihak-pihak lain yang berkepentingan atau berpotensi berkepentingan terhadap proses pendaftaran tanah tersebut. Mayoritas praktisi, terutama Kantor Pertanahan menafsirkan bahwa terhadap tanah negara yang dimohonkan haknya (untuk selanjutnya dinomenklaturkan sebagai pemberian hak), tidak ada kewajiban untuk mengumumkan data fisik atau data yuridis terlebih dahulu sebelum diberikan haknya.

Kendatipun sistem pendaftaran tanah di Indonesia sifatnya stelsel negatif, namun di dalamnya terdapat fase-fase yang 
bersifat obyektif untuk memastikan bahwa pendaftaran tanah yang dilakukan tidak akan menimbulkan akibat hukum merugikan bagi pihak lain yang berkepentingan terhadapnya. Fase itu diantaranya adalah pada saat pengukuran, terdapat kewajiban menghadirkan pihak yang berbatasan langsung dengan tanah yang diukur (Pasal 19 Peraturan Menteri Negara Agraria/Kepala Badan Pertanahan Nasional Nomor 3 Tahun 1997), serta pemenuhan asas publisitas itu sendiri (Pasal 63 ayat (2) maupun Pasal 86 ayat (2) Peraturan Menteri Negara Agraria/Kepala Badan Pertanahan Nasional Nomor 3 Tahun 1997).

Perlindungan hukum yang diberikan oleh Peraturan Pemerintah Nomor 24 Tahun 1997 tersebut, harus bersifat substansial, dalam arti kaidah-kaidah prosedural yang ditempuh haruslah memiliki makna dan arti yang sebenarnya, sejalan dengan tujuan perlindungan hukum tersebut dan tak hanya bersifat formal belaka. Terhadap dalam hal ini penulis berpendapat, berasal dari mana pun tanah yang dimohonkan oleh suatu subyek hukum, baik tanah konversi, tanah adat, apalagi tanah negara, haruslah tetap tunduk dan patuh pada kaidah pendaftaran tanah sebagaimana Peraturan Pemerintah Nomor 24 Tahun 1997, kecuali ada peraturan (regeling) lain yang mengubahnya.

Penetapan mengenai tanah negara, maupun pemberian hak atas tanah negara harus memiliki parameter yang jelas dan konsisten, sehingga tidak akan menimbulkan konflik dengan masyarakat terutama di daerah-daerah tertentu yang belum tersentuh norma-norma hukum positif, melainkan mengenal penguasaan tanah berdasarkan norma hukum adat saja.

Bila konsistensi mengenai kriteria dan prosedural pemberian hak atas tanah dari tanah negara belum dapat disusun mengingat kompleksnya kaidah hukum agraria adat di setiap wilayah Indonesia, maka konsistensi tersebut setidaknya harus dinisbahkan pada regulasi mengenai pendaftaran atau penerbitan sertipikat yang telah ada dan berlaku, yakni Peraturan Pemerintah Nomor 24 Tahun 1997.

Putusan Penerimaan Permohonan (Fiktif Positif) yang dibawa Undangundang Nomor 30 Tahun 2014, merupakan antitesis dari Gugatan Fiktif Negatif berdasarkan Pasal 3 Undang-undang Nomor 5 Tahun 1986. Salah satu dan pembeda utama dari keduanya adalah, bila berdasarkan ketentuan Pasal 3 ayat (2) Undang-undang Nomor 5 Tahun 1986, didiamkannya permohonan oleh Badan/Pejabat Tata Usaha Negara maka dianggap sebagai keputusan penolakan, maka berdasarkan ketentuan Pasal 53 ayat (3) didiamkannya permohonan oleh Badan/Pejabat Tata Usaha Negara maka dianggap sebagai keputusan penerimaan, yang selanjutnya dimohonkan kepada Pengadilan (Tata Usaha Negara).

Di dalam praktik peradilan administrasi, Putusan Penerimaan Permohonan kerap dijadikan trik/cara oleh pihak yang menginginkan pembatalan suatu keputusan, dengan selubung permohonan penerbitan keputusan. Contohnya dalam sengketa administrasi pertanahan, melalui dalih permohonan penerbitan sertipikat yang tidak ditanggapi oleh Badan Pertanahan, maka diajukanlah sengketa administrasi berjenis Putusan Penerimaan Permohonan disertai dengan permohonan pembatalan sertipikat yang telah ada (eksis) pada bidang tanah yang dimohonkan tersebut. Pengelabuan hukum semacam ini, bila tidak ditelaah dan dipahami secara mendalam akan menjadi celah untuk mengakali pembatalan sertipikat yang bisa saja telah diputus dan berkekuatan hukum tetap (baik dengan amar putusan ditolak atau tidak diterima) oleh Pengadilan di dalam gugatan sengketa tata usaha negara biasa.

Putusan Penerimaan Permohonan menurut pemahaman penulis, hanya berlaku pada lingkup ketiadaan sengketa (dispute) dengan pihak lain (individu maupun badan hukum), tidak disertai dengan permohonan pembatalan/pernyataan tidak sah keputusan 
lain yang sejenis/serupa, tidak disertai dengan penundaan keberlakuan keputusan lain yang sejenis/serupa, serta segala prosedur dan syarat telah dipenuhi oleh pemohon sehingga secara hukum tidak ada lagi alasan bagi badan/pejabat pemerintahan untuk menolak atau mengabaikan permohonan tersebut.

Sengketa Pengadaan Tanah dimunculkan berdasarkan Undang-undang Nomor 2 Tahun 2012 tentang Pengadaan Tanah Bagi Pembangunan Untuk Kepentingan Umum, yang merupakan evolusi dari regulasi yang sebelumnya berlaku, yakni Peraturan Presiden Nomor 36 Tahun 2005 tentang Pengadaan Tanah Bagi Pelaksanaan Pembangunan Untuk Kepentingan Umum, dan Peraturan Presiden Nomor 65 Tahun 2006 tentang Perubahan atas Peraturan Presiden Nomor 36 Tahun 2005 tentang Pengadaan Tanah Bagi Pelaksanaan Pembangunan Untuk Kepentingan Umum.

Pada prinsipnya yang menjadi obyek sengketa dalam sengketa pengadaan tanah di Pengadilan Tata Usaha Negara adalah penetapan lokasi pengadaan tanah. Berdasarkan ketentuan Pasal 19 ayat (6) Undang-undang Nomor 2 Tahun 2012, merupakan kewenangan dari Gubernur, yang dilakukan setelah terlebih dahulu melalui rangkaian konsultasi publik yang melibatkan pemegang hak atas tanah.

Secara konseptual, keberatan terhadap penetapan lokasi ini terlebih dahulu menempuh administratieve bezwaar karena dapat dimintakan keberatan kepada Gubernur ${ }^{25}$ sebagaimana diatur dalam ketentuan Pasal 20-21 Undang-undang Nomor 2 Tahun 2012. Baru setelah diprosesnya keberatan oleh Gubernur dinyatakan ditolak, penetapan lokasi itu dapat diajukan gugatan ke Pengadilan Tata Usaha Negara

${ }^{25} \mathrm{Hal}$ ini sebangun dengan ketentuan Pasal 48 Undangundang Nomor 5 Tahun 1986 yang menyatakan bila ada upaya administratif dalam suatu sengketa administrasi, maka diselesaikan terlebih dahulu secara internal di lingkup eksekutif. Kendati demikian terdapat lex specialis dalam hal kewenangan mengadili sengketa pengadaan tanah yang menempatkan Pengadilan Tata Usaha Negara sebagai pemeriksa tingkat pertama, berbeda dengan konteks pasal 48 jo. Pasal 51 ayat (3) Undang-undang Nomor 5 Tahun 1986. sebagaimana ketentuan Pasal 23 ayat (1) Undang-undang Nomor 2 Tahun 2012.

Selanjutnya Pengadilan Tata Usaha Negara wajib memutus gugatan tersebut dalam waktu 30 hari sejak diterimanya gugatan oleh Pengadilan, hal ini termuat dalam ketentuan Pasal 23 ayat (2) Undangundang Nomor 2 Tahun 2012 jo. Pasal 11 ayat (1) Peraturan Mahkamah Agung Nomor 2 Tahun 2016. Dan bila masih tidak puas atas putusan tersebut, maka upaya hukum yang dapat dilakukan terhadapnya adalah Kasasi sebagaimana ketentuan Pasal 23 ayat (3) Undangundang Nomor 2 Tahun 2012.

Dalam sengketa administrasi pertanahan, yang berwenang untuk melakukan pembatalan atau dinyatakan tidak sahnya suatu sertipikat adalah instansi yang menerbitkannya, dimana berdasarkan Undang-undang Nomor 30 Tahun 2014 maupun Peraturan Menteri Negara Agraria/Kepala Badan Pertanahan Nasional bisa jadi dilakukan oleh instansi yang berbeda secara hierarkhis, yakni Kepala Kantor Pertanahan, Kepala Kantor Wilayah Badan Pertanahan Nasional atau oleh Kepala Badan Pertanahan Nasional sendiri.

Pelaksanaan putusan, dalam hal dibatalkan atau tidak dinyatakan sahnya sertipikat hak atas tanah, praktiknya dilakukan oleh Kantor Wilayah Badan Pertanahan atau Badan Pertanahan Nasional dengan menerbitkan surat keputusan yang bersubstansikan pencabutan surat keputusan sebelumnya yang memberikan hak atas tanah kepada subyek hukum tertentu, yang kemudian menjadi dasar bagi Kantor Pertanahan untuk melakukan pembatalan sertipikat hak atas tanah.

Terdapat 2 persoalan yang berpotensi terjadi dalam fase pelaksanan putusan oleh Badan Pertanahan Nasional (dan/atau instansi bawahannya) ini, yakni:

1. Tidak tepatnya obyek sengketa yang dinyatakan batal atau tidak sah oleh Pengadilan. Hal ini telah disinggung 
dalam bahasan mengenai kedudukan sertipikat hak atas tanah sebagai keputusan tata usaha negara, yang inti persoalannya muncul hanya tatkala Badan Pertanahan Nasional (dan/atau instansi bawahannya) memiliki iktikad tidak baik dalam melaksanakan putusan pengadilan. Sebagaimana telah dibahas pula sebelumnya, pembatalan sertipikat hak atas tanah, secara konsep administratif tidak serta merta membatalkan keputusan pemberian hak atau dasar terbitnya hak, karena hanya berkedudukan sebagai keputusan yang bersifat deklaratif saja. Sedikit saja ada pengelakan dari Badan Pertanahan Nasional (dan/atau instansi bawahannya) terkait eksistensi dan legalitas dokumen pertanahan tersebut, maka secara hukum sebenarnya bisa saja pembatalan atau pernyataan tidak sahnya suatu sertipikat hak atas tanah, tidak bernilai manfaat bagi si Penggugat sebab SKPH maupun Buku Tanah dan Gambar Situasi atau Surat Ukur yang menjadi dasar diterbitkannya sertipikat tidak ikut digugat. Dengan demikian, harus dilakukan reposisi terhadap kedudukan obyek sengketa administrasi pertanahan di Peradilan Administrasi, yakni menempatkan obyek sengketa yang tepat dan bersifat konstitutif.

2. Oleh sebab obyek sengketa administrasi pertanahan yang umum adalah masih berupa sertipikat hak atas tanah, maka kendati telah dibatalkan atau dinyatakan tidak sahnya suatu sertipikat, tidak secara otomatis memerintahkan kepada pemegang sertipikat untuk mengembalikan sertipikat tersebut kepada Badan Pertanahan Nasional (dan/atau instansi bawahannya). Inilah yang juga menjadi persoalan dalam pelaksanaan putusan, sebab terdapat potensi kendati telah dinyatakan batal atau tidak sah, sertipikat yang tidak dikembalikan ke Badan Pertanahan Nasional (dan/atau instansi bawahannya) baik secara sukarela maupun paksaan, masih memiliki nilai ekonomi dan dapat dilakukan tindakan hukum terhadapnya, kendati ilegal.

Tidak adanya lembaga sita di dalam proses penegakan Hukum Administrasi, merupakan celah lain yang bisa dimanfaatkan untuk menggagalkan penegakan hukum administrasi yang bermanfaat serta berkeadilan. Lain halnya apabila yang dijadikan obyek sengketa adalah SKPH atau Buku Tanah dan Gambar Situasi/Surat Ukur yang tentu berada pada penguasaan Badan Pertanahan Nasional (dan/atau instansi bawahannya).

\section{SIMPULAN}

1. Konsepsi Hak atas tanah yang dibawa UUPA, lebih menitikberatkan pada pemanfaatan dan pendayagunaan tanah. Sementara Sertipikat tanah sejalan dengan stelsel negatif bertendensi positif, hanya membuktikan bahwa pemegang hak mempunyai suatu hak atas bidang tanah tertentu. Hal yang tidak selalu paralel antara pemanfaatan dan pendayagunaan tanah dengan pemilikan sertipikat. Perlindungan terhadap hak dan keabsahan sertipikat berpijak pada iktikad baik dan penguasaan yang nyata dalam pendaftaran haknya.

Kendati sertipikat hak atas tanah secara praktek lebih banyak didudukan sebagai obyek dalam sengketa administrasi, akan tetapi disahkannya Undang-undang Nomor 30 Tahun 2014, hendaknya menjadi acuan untuk mereposisi kedudukan sertipikat hak atas tanah sebagai obyek dalam sengketa adaministrasi, dan menggantikannya dengan dokumen pertanahan yang lebih tepat.

2. Problematika Penegakan Hukum Administrasi Dalam Sengketa Di Bidang Pertanahan, secara umum dibagi menjadi 3 bagian utama pengujian, yakni aspek kewenangan penerbitan sertipikat, aspek prosedural sertipikat dan aspek substansial penerbitan sertipikat. 
Kedudukan sertipikat hak atas tanah sebagai obyek sengketa administrasi, juga harus menjadi bahan kajian dan telaahan, mengingat sejatinya terdapat keputusan lain yang bersifat konstitutif, yakni SKPH serta Buku Tanah dan Gambar Situasi/Surat Ukur.

Selain problematika dengan obyek sengketa sertipikat hak atas tanah, jenis sengketa administrasi pertanahan yang menjadi kewenangan peradilan administrasi untuk memeriksa, memutus dan menyelesaikannya dapat dibedakan menjadi 3 tipikal, yakni: 1). sengketa tata usaha negara (gugatan) mengenai keabsahan dokumen pertanahan dengan obyek sengketa mayoritas berupa sertipikat hak atas tanah; 2). putusan penerimaan permohonan, mengenai keabsahan tindakan (penolakan) di bidang administrasi pertanahan; dan 3). sengketa pengadaan tanah, dengan obyek sengketa berupa penetapan lokasi pengadaan tanah.

3. Dalam praktik penegakan hukum administrasi, dasar ilegalitas sertipikat hak atas tanah mayoritas berkenaan dengan tidak akuratnya atau tidak dilaksanakannya pengukuran, penetapan batas bidang tanah maupun pengumuman data fisik dan data yuridis bidang tanah yang didaftarkan haknya, serta inkonsistensi penerapan maupun konflik norma terkait dengan penetapan tanah negara dalam suatu pemberian hak atas tanah negara. Adapun pelaksanaan putusan atas ilegalitas sertipikat hak atas tanah yang dinyatakan Pengadilan, secara praktis dilaksanakan atas dasar kesadaran badan/pejabat pemerintahan itu sendiri. Hambatan yang berpotensi timbul adalah tatkala sertipikat yang telah dibatalkan/dinyatakan tidak sah, tidak diberikan secara sukarela oleh pemegang hak sehingga salah satu solusinya adalah dengan membentuk lembaga penyitaan sebagai salah satu norma positif dalam penegakan hukum administrasi.

\section{DAFTAR PUSTAKA}

Adrian Sutedi, Sertifikat Hak Atas Tanah, Sinar Grafika, Jakarta, 2014

AP. Parlindungan, Pendaftaran Tanah Di Indonesia, Mandar Maju, Bandung, 1999.

Arie S. Hutagalung, Tebaran Pemikiran Seputar Masalah Hukum Tanah, Lembaga Pemberdayaan Hukum Indonesia, Jakarta, 2005

Budi Harsono, Hukum Agraria Indonesia: Sejarah Pembentukan Undangundang Pokok Agraria, Isi dan Pelaksanaannya, cetakan ke-12, Djambatan, Jakarta, 2008.

Dani Elpah, Titik Singgung Kewenangan Antara Peradilan Tata Usaha Negara Dengan Peradilan Umum Dalam Sengketa Pertanahan, Laporan Penelitian, Bogor, Balitbang Diklatkumdil, 2014.

Direktorat Jenderal Badan Peradilan Militer dan Peradilan Tata Usaha Negara Mahkamah Agung Republik Indonesia, Statistik Perkara Peradilan Tata Usaha Negara Seluruh Indonesia Tahun 2015, Jakarta, 2016

Elza Syarief, Menuntaskan Sengketa Tanah Melalui Pengadilan Khusus Pertanahan, Kepustakaan Populer Gramedia, Jakarta, 2004.

Indroharto, Usaha Memahami Undangundang tentang Peradilan Tata Usaha Negara, Buku I, Pustaka Sinar Harapan, 2000.

Maria SW Soemardjono, Kebijakan Pertanahan. Antara Regulasi dan Implementasi, Cetakan VI, Penerbit Buku Kompas, Jakarta, 2009.

Muhammad Ilham Arisaputra, Reforma Agraria Di Indonesia, Sinar Grafika, Jakarta Timur, 2015. 
Nia Kurniati, Hukum Agraria: Sengketa Pertanahan Penyelesaiannya Melalui Arbitrase Dalam Teori dan Praktik, Refika Aditama, Bandung, 2016.

Philipus M. Hadjon, dkk. Pengantar Hukum Administrasi Indonesia: Introduction to the Indonesian Administrative Law, Cetakan ke-8, Gadjah Mada University Press, Yogyakarta, 2002.

Ridwan HR, Hukum Administrasi Negara,
PT RajaGrafindo Persada, Jakarta, 2006.

Rusmadi Murad, Menyingkap Tabir Masalah Pertanahan, Penerbit Mandar Maju, Bandung, 2000.

S.F. Marbun, Peradilan Administrasi dan Upaya Administrasi di Indonesia, Penerbit UII Press, Yogyakarta, 2003.

Sarjita, Teknik dan Strategi Penyelesaian Sengketa Pertanahan, Tugojogja Pustaka, Yogyakarta, 2005. 